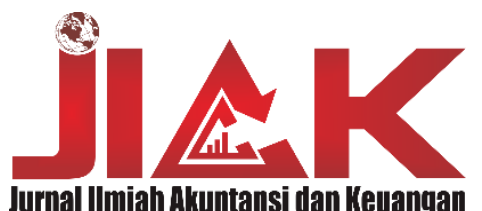

http://journal.stieputrabangsa.ac.id/index.php/jiak

ISSN: 2580-510X/ P-ISSN: 2548-9453

ARTICLE INFORMATION

Received February $9^{\text {th }} 2021$

Accepted June $12^{\text {th }} 2021$

Published June $12^{\text {st }} 2021$

DOI:

https://doi.org/10.32639/jiak. v9i2.743

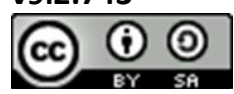

\section{Mediation Effect of Financial Performance on The Influence of Intellectual Capital on Firm Value}

\author{
Hidayatul Khusnah ${ }^{1}$, Mardiyah Anugraini ${ }^{2}$ \\ ${ }^{1,2)}$ Universitas Nahdlatul Ulama Surabaya \\ email: hidayatul.khusnah1989@gmail.com ${ }^{1}$
}

\begin{abstract}
This study aims to determine the mediating effect of financial performance on the effect of intellectual capital on firm value. This research was conducted at companies incorporated in LQ-45 listed on the Indonesian stock exchange. The sample of this research is the financial statements of companies incorporated in LQ-45 in the 2014-2019 period that publish financial statements continuously. Analysis of the data in this study using SEM-PLs using WarpPLs 6.0 software. The results of this study indicate that VACA, VAHU and STVA have a positive effect on firm value. In addition, this study also found that of the three intellectual capital proxies, only VACA and STVA had a positive effect on financial performance, while VAHU did not support the research hypothesis because it had a negative effect on financial performance. Further findings show that financial performance mediates the effect of VACA and STVA on firm value.
\end{abstract}

Keywords: Intellectual Capital; Financial Performance; Firm Value

\title{
INTRODUCTION
}

Companies now realize that competitiveness is not only in tangible assets, but more emphasis on information systems, innovation, management of the organization and its resources (Chen et al, 2005). Therefore, companies must be able to increase their competitiveness to be superior to other companies. Regarding this Sawarjuwono (2003) argues that companies must make changes to business processes, from what was originally based on labor (labor based business) to a business based on knowledge (knowledge-based business), so that the structure of the company's main characteristics becomes a company that is based on knowledge. Companies that implement knowledge-based business will create an idea to manage knowledge as a means to obtain income in the company, by implementing knowledge-based businesses, the company's value will also change.

If a financial report is made properly and accurately, it can describe the real condition of the company in terms of achievement within a certain period of time. From preparing the company's financial statements, it also aims to determine the profitability and level of risk or the level of smoothness of a company (Suhardiyah et al, 2018). In competition in the era of globalization, developments in the business world have resulted in increasingly fierce competition among companies. Therefore, the 
company must be able to increase its competitiveness to be superior to other companies. In Indonesia, there are many company sectors, but being in the LQ45 stock index is an advantage that can be trusted by investors because the level of liquidity in the company is good. The LQ45 stock index is an index consisting of 45 selected stocks that have high liquidity value and large market capitalization and are selected through several criteria in selection. This index is selected every six months, namely at the beginning of February and August (Prima et al., 2018). With the promising business prospects, it will attract investors to invest.

Regarding these problems, the company's value is considered very important and is the main object for the company to continue to improve its company's performance as a going concern for the company in the future. Company value can describe the condition of a company where the conditions that have been achieved by the company as a picture of the company's prospects trust in the future. Firm value is a reflection of market value that is able to provide maximum prosperity for shareholders if the share price continues to increase. The value of the company can be said to have increased when viewed from the increase in its share price. The higher the stock price in a company, the higher the value of the company (Westerfield \& Jaffe, 2013).

This study aims to investigate the mediating effect of financial performance on the effect of intellectual capital on firm value. The sample of this research is the financial statements of companies incorporated in LQ-45 in the 2014-2019 period that publish financial statements continuously. Analysis of the data in this study using SEM-PLs using WarpPLs 6.0 software. The results of this study indicate that VACA, VAHU and STVA have a positive effect on firm value. In addition, this study also found that of the three intellectual capital proxies, only VACA and STVA had a positive effect on financial performance, while VAHU did not support the research hypothesis because it had a negative effect on financial performance. Further findings show that financial performance mediates the effect of VACA and STVA on firm value.

\section{LITERATURE REVIEW AND HYPOTHESIS DEVELOPMENT}

Resource Based Theory in this theory assumes that the company will create company value by maximally managing and using VACA or physical resources in accordance with the capabilities of the company. If VACA can be managed effectively and efficiently, it will improve company performance (Randa and Solon, 2012). If the resources owned by the company affect the company's financial performance, it will ultimately increase the company value which can be seen from the company's stock price. One of the disclosed intangible asset resources is VACA (Aida and Rahmawati, 2015).

According to research conducted by Sayyidah and Saifi (2017) it shows that VACA has no significant effect on firm value. However, in this study, financial performance has a significant effect in mediating the effect of VACA on firm value. This shows that even though VACA has not been able to increase firm value, if the company can manage its capital assets properly, it can improve the company's performance. Based on the description above, the following hypotheses can be concluded:

\section{$\mathrm{H}_{1}$ : Financial Performance mediates the effect of Value Added Capital Employed (VACA) on firm value}

VAHU is the main component of intellectual capital because human interaction is a source of intangible value in intellectual property. The company views the same between VAHU and other production factors such as machines. Management views that employees if they do not do their job properly, they will be easily replaced with new ones (Fariana, 2014). If the company can manage and make good use of the human and intellectual resources owned by the company, it will affect the company's profits or increased financial performance and this will affect the company's value. 
According to research conducted by Nuryaman (2015), it shows that VAHU has a positive influence on firm value. Then financial performance on firm value has a positive effect and in this study financial performance can be used as a mediating variable between the effect of VAHU on firm value. This shows that the company is able to employ employees who are committed and competent. Committed and competent employees need to be supported by a good company infrastructure, so the three combinations can improve company performance and company value. Based on the description above, the following hypotheses can be concluded:

\section{$\mathrm{H}_{2}$ : Financial Performance mediates the effect of Value Added Human Capital (VAHU) on firm value}

Resource Based Theory states that the company has resources that can make the company have a competitive advantage and be able to direct the company to have good long-term performance (Ulum, 2017). Utilization of company resources will run well if it is supported by the company's STVA capability properly. Companies will provide a higher assessment to companies that have increased financial performance, with increased financial performance, investors will respond positively and will increase the company's value (Yuskar and Novita, 2014).

According to research conducted by Jayanti and Binastuti (2017), it shows that STVA has no effect on firm value. However, STVA which is considered to have no effect is successfully mediated by financial performance through company value with a good ROA level that will affect good company value. This shows that the company can optimize the use of company resources properly. Based on the description above, the following hypotheses can be concluded:

\section{$\mathrm{H}_{3}$ : Financial Performance mediates the effect of Structural Capital Value Added (STVA) on Firm Value}

\section{METHOD}

The sample in this study were 22 publicly traded companies that were included in the LQ-45 stock group during 2014-2019. There are 132 data that were examined in this study.

\section{Variable Measurement}

Intellectual Capital (X1)

Intellectual capital is intangible capital related to technology and knowledge, which includes hidden value for a company that can increase the company's competitiveness (Arini, 2018). Intellectual capital in this study was proxied by the Value Added Coefficient (VAICTM) component. The first step in calculating VAICTM is calculating VA (Value Added). VA is an effective indicator to assess the success of a business and shows the company's ability to create value (value creation). VA is calculated as the difference between output and input. VA can be formulated as follows:

$$
\text { VA }=\text { OUT-IN }
$$

VA : Value Added (the difference between output and input)

OUT : Output (Total sales and other revenues)

IN : Input (selling expenses and other expenses, other than employee expenses).

Value Added Capital Employed (VACA)

VACA is the company's ability to manage resources in the form of well-managed capital assets so that it can increase financial work (Dewi, 2011 quoted by Nurfauzia, 2018). With the following formula: 


$$
V A C A=\frac{V A}{C E}
$$

VA : Value Added

CE : Capital Employed (book value of net assets)

\section{Value Added Human Capital (VAHU)}

The VAHU shows how much VA is generated in the monetary unit issued by the company for employees or labor. This ratio shows the contribution made by each company that is invested in human capital to the value added of a company, the costs incurred by the company related to labor costs are reported in the salary expense contained in the company's financial statements (Nurfauzia, 2018). The formula is as follows:

$$
V A H U=\frac{V A}{H C}
$$

VA : Value Added

HC : Human Capital (employee expenses).

\section{Stuctural Capital Value Added (STVA)}

This ratio measures the amount of structural capital (SC) needed to create value, STVA measures the amount of SC needed to produce rupiah VA and indicates how successful SC is in value creation (Nurfauzia, 2018). The equation in this calculation is:

$$
S T V A=\frac{S C}{V A}
$$

SC : Structural Capital (the difference between VA and HC)

VA : Value Added (the difference between output and input).

\section{Value Added Intellectual Capital (VAIC ${ }^{\mathrm{TM}}$ )}

VAIC $^{T M}$ is a method used to measure the intellectual model of a company, each of which has advantages and disadvantages so that in choosing the right model to use it is an inappropriate action because the measurement is only a tool used for situations and conditions with certain specifications, the formula for calculating VAICTM are as follows:

$$
\text { VAIC }^{\mathrm{TM}}=\text { VACA+VAHU+STVA }
$$

\section{Firm Value}

According to Hidayat (2018), company value is a value that reflects what price investors will pay for a company. In this study, the measurement of firm value uses the price book value (PBV). PBV is the result of a comparison between the share price and the book value of the shares, if the PBV value is high, market confidence will increase in the company's prospects and indicate. prosperity of the good shareholders. The PBV formula is as follows:

$$
P B V=\frac{\text { stock market price }}{\text { bookvalue }}
$$




\section{Financial Performance}

financial performance using profitability ratios. Profitability is a measure in measuring the percentage used to assess the company in generating profits at an acceptable level. In this study the profitability ratio is proxied by return on assets (ROA). Here is the formula for calculating ROA:

$$
\text { ROA }=\frac{\text { net profit }}{\text { total assets }}
$$

\section{RESULT AND DISCUSSION}

The following are the results of hypothesis testing in this study presented in the table below:

Table 1. Research Hypothesis Testing Results

\begin{tabular}{|c|c|c|}
\hline \multicolumn{3}{|c|}{ Tabel A Direct Relationship } \\
\hline \multicolumn{2}{|l|}{ Variable } & Firm Value \\
\hline \multicolumn{2}{|l|}{ VACA } & $0,53 * * *$ \\
\hline \multicolumn{2}{|l|}{ VAHU } & $0,54 * * *$ \\
\hline \multicolumn{2}{|l|}{ STVA } & $0,32 * * *$ \\
\hline \multicolumn{3}{|c|}{ Tabel B Inirect Relationship } \\
\hline Variable & $\begin{array}{c}\text { Financial } \\
\text { Performance }\end{array}$ & Firm Value \\
\hline VACA & $0,33^{* * *}$ & $0,52 * * *$ \\
\hline VAHU & $-0,19$ & $0,41 * * *$ \\
\hline STVA & $0,44 * * *$ & $0,24 * *$ \\
\hline FP & & $0,36 * * *$ \\
\hline
\end{tabular}

Source: Data processed (2020)

Table 2. Results of the calculation of the VAF Hypothesis of Mediation

\begin{tabular}{|c|c|c|}
\hline \multicolumn{3}{|l|}{ Indirect Relationship } \\
\hline $\mathrm{VACA} \rightarrow \mathrm{FP} \rightarrow \mathrm{FV}$ & $0,33 * 0,52$ & 0,172 \\
\hline STVA $\rightarrow$ FP $\rightarrow$ FV & $0,44 * 0,24$ & 0,106 \\
\hline \multicolumn{2}{|c|}{ Total Indirect Relationship } & 0,278 \\
\hline \multicolumn{3}{|l|}{ Direct Relationship } \\
\hline \multirow{2}{*}{\multicolumn{2}{|c|}{$\begin{array}{l}\text { STVA } \rightarrow \text { FV } \\
\text { Total Direct relationship }\end{array}$}} & \multirow{2}{*}{0,24} \\
\hline & & \\
\hline Total relationship & $0,24+0,278=0,518$ & \\
\hline \multirow{2}{*}{$\operatorname{VAF}(\mathrm{VACA} \rightarrow \mathrm{FP} \rightarrow \mathrm{FV})$} & Indirect relationship $\quad 0,172$ & \multirow{2}{*}{0,33} \\
\hline & $\overline{\text { Total relationship }}=\frac{}{0,518}$ & \\
\hline \multirow{2}{*}{$\operatorname{VAF}(\mathrm{STVA} \rightarrow \mathrm{FP} \rightarrow \mathrm{FV})$} & Indirect relationship $\quad 0,106$ & \multirow{2}{*}{0,20} \\
\hline & $\overline{\text { Total relationship }}=\overline{0,518}$ & \\
\hline
\end{tabular}

Source: Data processed (2020)

\section{Discussion}

Based on the results of hypothesis testing which have been shown in tables 1, 2 and 3 above, it can be seen that (VACA - FP - FV) has a path coefficient value of 0.32 and 0.26 and a VIF calculation value of 0.33 . These results indicate that financial performance is able to mediate the effect of VACA on firm value. 
These results are in line with research conducted by Utari (2018) which states that financial performance is able to mediate the effect of VACA on Firm Value.

In this study, non-financial companies are able to use the company's capital assets efficiently, so that they can increase the company's net profit. With increased net profit, it can improve the company's financial performance. The better the growth in financial performance of the company, the more investors are interested in investing so that the company's value also increases, which can be seen in its share price. The results of this study support the Resources Based Theory (RBT) which states that companies can create added value by managing and using the company's capital assets efficiently so that they can increase profits in the company (Simanungkalit and Prasetiono, 2015).

Furthermore, it is known that (VAHU - FP - FV) has a path coefficient value of -0.18 and 0.26 . These results do not meet the VIF calculation test. So that financial performance does not mediate the effect of VAHU on firm value.

\section{CONCLUSION}

The results of the latest research in this study indicate that (STVA - FP - FV) has a path coefficient value of 0.45 and 0.26 and a VIF calculation value of 0.20 . These results indicate that financial performance mediates the effect of STVA on firm value. This shows that the facilities and infrastructure that have been provided to employees can optimally make employees feel comfortable so that employees can be motivated to increase their productivity and performance and the company can meet sales targets. So that the company will experience an increase in financial performance which then has an impact on the increase in company value which can be seen in its share price. The results of this study support the Resources Based Theory (RBT) which states that if the company can manage and use structural capital optimally, it can increase the value for the company (Simanungkalit and Prasetiono, 2015).

\section{REFERENSI}

Ahmad, A. S., Bone, H., \& Kusumawardani, A. (2019). Pengaruh struktur modal terhadap kinerja keuangan pada perusahaan pembiayaan yang terdaftar di bursa efek indonesia 2011-2016. Jurnal IImu Akuntansi Mulawarman (JIAM), 3(4).

Antari, D. A. P. P., \& Dana, I. M. (2013). Pengaruh struktur modal, kepemilikan manajerial, dan kinerja keuangan terhadap nilai perusahaan. E-Jurnal Manajemen, 2(3), 274-288.

Arini, Y. (2018). Pengaruh Intellectual Capital Dan Good Corporate Governance Terhadap Nilai Perusahaan Melalui Kinerja Keuangan (Studi Pada Perusahaan Subsektor Perbankan Yang Listing Di Bei Periode 2013-2016). Jurnal Ilmu Manajemen (JIM), 6(3), 227-240.

Astiti, N. P. Y. (2015). Pengaruh Profitabilitas dan Struktur Asset terhadap Struktur Modal pada Perusahaan Property and Real Estate yang Terdaftar di Bursa Efek Indonesia. Jurnal IImu Manajemen (JUIMA), 5(2).

Bontis, N., William Chua Chong, K., \& Richardson, S. (2000). Intellectual capital and business performance in Malaysian industries. Journal of Intellectual Capital, 1(1), 85-100.

Chen, M. C., Cheng, S. J., \& Hwang, Y. (2005). An empirical investigation of the relationship between intellectual capital and firms' market value and financial performance. Journal of Intellectual Capital, 6(2), 159-176. 
Cuong, N. T., \& Canh, N. T. (2012). The effect of capital structure on firm value for Vietnam's seafood processing enterprises. International Research Journal of Finance and Economics, 89(89), 221-233.

Deegan, C. (2004). Environmental disclosures and share prices - A discussion about efforts to study this relationship. Accounting Forum, 28(1), 87-97.

Dewi, I. (2014). Pengaruh Struktur Modal Terhadap Nilai Perusahaan (Studi Pada Sektor Pertambangan Yang Terdaftar Di Bei Periode 2009-2012). Jurnal Administrasi Bisnis, 17(1).

Dewi, W., \& Lestari, H. S. (2014). Faktor-Faktor Penentu Struktur Modal Perusahaan Non Keuangan yang Terdaftar di Bursa Efek Indonesia. Jurnal Manajemen dan Pemasaran Jasa, 7(2), 273-294.

Dwi, M., Astri, P., \& Susanto, A. (2008). Analisis Pengaruh Human Capital Terhadap Kinerja Perusahaan (Studi Empiris pada Kantor Akuntan Publik di Indonesia). Jurnal Akuntansi Dan Keuangan, 10(1), 11-21.

Faradina, I. (2016). Pengaruh Intellectual Capital Dan Intellectual Capital Disclosure Terhadap Kinerja Keuangan Perusahaan. E-Jurnal Akuntansi, 15(2), 1623-1653.

Firer, S., \& Mitchell Williams, S. (2003). Intellectual capital and traditional measures of corporate performance. Journal of Intellectual Capital, 4(3), 348-360.

Gamayuni, R. R. (2015). The Effect Of Intangible Asset Financial Performance And Financial Policies On The Firm Value. International Journal of Scientific \& Technology Research, $4(1), 202-212$.

Hamel, G., Prahalad, C. K., Ansoff, H. I., Works, L. A., Voss, B., Dold, L., ... Sunzi. (2007). No

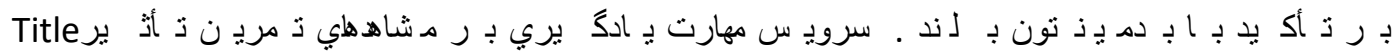
117. https://doi.org/10.23943/9781400889877

Hamidah, H., Ahmad, G. N., \& Aulia, R. (2015). Effect of Intellectual Capital, Capital Structure and Managerial Ownership Toward Firm Value of Manufacturing Sector Companies Listed in Indonesia Stock Exchange (Idx) Period 2010-2014. JRMSI - Jurnal Riset Manajemen Sains Indonesia, 6(2), 558

Hamidy, R. R., Wiksuana, I. G. B., \& Artini, L. G. S. (2015). Pengaruh struktur modal terhadap nilai perusahaan dengan profitabilitas sebagai variabel intervening pada perusahaan properti dan real estate di bursa efek Indonesia. E-Jurnal Ekonomi dan Bisnis Universitas Udayana, 4(2015), 665-682.

Hidayat, A. R. (2018). Pengaruh Profitabilitas Dan Likuiditas Terhadap Harga Saham Pada Perusahaan Manufaktur Sub Sektor Makanan Dan Minuman Yang Terdaftar Di Bursa Efek Indonesia. 6, 59-72.

Irayanti, D., \& Tumbel, A. (2014). Analisis Kinerja Keuangan Pengaruhnya Terhadap Nilai Perusahaan Pada Industri Makanan Dan Minuman Di Bei. Jurnal Riset Ekonomi, Manajemen, Bisnis Dan Akuntansi, 2(3), 1473-1482. 
Israel, C., Mangantar, M., \& Saerang, I. S. (2018). Pengaruh Struktur Modal, Kepemilikan Institusional dan Ukuran Perusahaan Terhadap Nilai Perusahaan Pada Perusahaan Pertambangan yang Terdaftar di BEI. Jurnal EMBA, 6(3), 1118-1127.

Kristianti, I. P. (2018). Analisis pengaruh struktur modal terhadap kinerja keuangan perusahaan. Akuntansi Dewantara, 2(1), 56-68.

Lestari, L. (2017). Pengaruh Kepemilikan Institusional dan Struktur Modal Terhadap Nilai Perusahaan. Jurnal Riset Manajemen dan Bisnis (JRMB) Fakultas Ekonomi UNIAT, 2, 293306.

Lestari, N., \& Sapitri, R. C. (2016). Pengaruh Intellectual Capital Terhadap Nilai Perusahaan. Jurnal Akuntansi, Ekonomi Dan Manajemen Bisnis, 4(1), 28-33.

Maryanti, E. (2016). Analisis Profitabilitas, Pertumbuhan Perusahaan, Pertumbuhan Penjualan dan Struktur Aktiva terhadap Struktur Modal pada Perusahaan Sektor Industri Barang Konsumsi yang terdaftar di Bursa Efek Indonesia (Studi Empiris pada Perusahaan Manufaktur yang Terdaftar di Bursa Efek Indonesia Tahun 2012-2014). Riset Akuntansi dan Keuangan Indonesia, 1(2), 143-151.

Meles, A., Porzio, C., Sampagnaro, G., \& Verdoliva, V. (2016). The impact of intellectual capital efficiency on commercial bank performance: Evidence from the US. Journal of Multinational Financial Management, 36, 64-74.

Novita, B. A., \& Sofie, S. (2015). Pengaruh struktur modal dan likuiditas terhadap profitabilitas. Jurnal Akuntansi Trisakti, 2(1), 13-28.

Nurhayati, M. (2013). Profitabilitas, likuiditas dan ukuran perusahaan pengaruhnya terhadap kebijakan dividen dan nilai perusahaan sektor non jasa. Jurnal Keuangan \& Bisnis Program Studi Magister Manajemen Sekolah Tinggi Ilmu Ekonomi Harapan, 5(2), 144153.

Permatasari, D., \& Azizah, D. F. (2017). Pengaruh Struktur Modal Terhadap Kinerja Keuangan Perusahaan Manufaktur Sektor Makanan Dan Minuman Yang Terdaftar Di Bursa Efek Indonesia Tahun 2013-2016. Jurnal Riset Manajemen, 219-232.

Prakarsa, L. M., \& Tarigan, J. (2016). Pengaruh kepuasan pelanggan terhadap kinerja keuangan melalui loyalitas pelanggan sebagai variabel intervening pada berbagai sektor perusahaan di Indonesia. Business Accounting Review, 4(1), 362-372.

Prima, R., Ananto, R. P., \& Rafi, M. (2018). Pengaruh Struktur Modal , Profitabilitas , Ukuran Perusahaan dan Modal Intelektual Terhadap Nilai Perusahaan Pada Indeks LQ 45 Periode 2010-2017. Jurnal Akuntansi \& Manajemen, 13(2), 93-111.

Pulić, A. (2008). The Principles of Intellectual Capital Efficiency - A Brief Description. Croatian Intellectual Capital Center, (76), 1-24.

Rachmawati, E. N., Hayati, R., \& Yulandi, F. (2018, March). The influence of intellectual capital on financial performance in sharia banking companies. In 15th International Symposium on Management (INSYMA 2018) (pp. 58-61). Atlantis Press. 
Sadalia, I., Daulay, I. E., Marlina, L., \& Muda, I. (2019). The influence of intellectual capital towards financial performance with brand value as an intervening variable. Quality Access to Success, 20(168), 79-85.

Santiani, N. P. (2018). Pengaruh Intellectual Capital Dan Struktur Modal Terhadap Nilai Perusahaan. 13(2), 69-78.

Sawarjuwono, T. (2003). Intellectual Capital: Perlakuan, Pengukuran Dan Pelaporan (Sebuah Library Research). Jurnal Akuntansi Dan Keuangan, 5(1), 35-57.

Subaida, I., Nurkholis, N., \& Mardiati, E. (2018). Effect of Intellectual Capital and Intellectual Capital Disclosure on Firm Value. Jurnal Aplikasi Manajemen, 16(1), 125-135.

Suparno, S., \& Ramadini, R. (2017). Pengaruh Intellectual Capital dan Earning PerShare terhadap Nilai Perusahaan (Studi Empiris pada Perusahaan LQ45 yang Terdaftar di Bursa Efek Indonesia Periode 2010-2014). Jurnal Manajemen Dan Keuangan Unsam, 6(1), 710-718.

Ulum, I., Ghozali, I., \& Chariri, A. (2008). Intellectual Capital Dan Kinerja Keuangan Perusahaan ; Suatu Analisis Dengan Pendekatan Partial Least Squares. Simposium Nasional Akuntansi $\mathrm{XI}, 19(19), 23-24$.

Veronica, T. M. (2013). pengaruh good corporate governance, CSR dan Kinerja keuangan terhadap nilai perusahaan. Jurnal Dinamika Manajemen, 4(2), 132-149.

Wahyuningtyas, I. (2014). Pengaruh Rasio Leverage, Rasio Intensitas Modal Dan Pangsa Pasar Terhadap Kinerja Keuangan. E-Journal Kewirausahaan, 2, 52-61.

Widarjo, W. (2011). Pengaruh Modal Intelektual Dan Pengungkapan Modal Intelektual Pada Nilai Perusahaan Yang Melakukan Initial Public Offering. Jurnal Akuntansi Dan Keuangan Indonesia, 8(2), 157-170.

Wirajaya, A. (2013). Pengaruh Struktur Modal, Profitabilitas Dan Ukuran Perusahaan Pada Nilai Perusahaan. E-Jurnal Akuntansi, 4(2), 358-372.

Wirawan, putu deddy, \& Suardana, ida bagus raka. (2018). Kualitas Laba Dan Pengaruhnya Terhadap Tingkat Efektifitas Pengenaan Pajak: Studi Empiris Pada Perusahaan Manufaktur. Jurnal IImiah Akuntansi \& Bisnis, 3(1), 82-92.

Yang, P., Dalam, T., \& Kompas, I. (2013). Analisis Pengaruh Struktur Modal Terhadap Kinerja Perusahaan Yang Tergabung Dalam Indeks Kompas 100. Management Analysis Journal, 2(1), 1-7.

Yulandari, L. F., \& Gunawan, H. (2019). Pengaruh Intellectual Capital Terhadap Nilai Pasar Dan Kinerja Keuangan Perusahaan Yang Terdaftar Di Bursa Efek Indonesia. Journal of Applied Managerial Accounting, 3(1), 36-50. 